\title{
Islamic Perspective on Importance of Breastfeeding: Two Case Reports
}

\author{
Nurhawa Mokhtar ${ }^{1}$, Fatin Syuhadah Sulaiman ${ }^{1}$, Anisa Kusumawardani ${ }^{2}$, Taufiq Hidayat ${ }^{3}$ \\ ${ }^{1}$ Final Year MBBS Programme, Kulliyyah of Medicine, International Islamic University Malaysia Kuantan. \\ ${ }^{2}$ Kulliyyah of Dentistry, International Islamic University Malaysia Kuantan. \\ ${ }^{3}$ Department of Paediatrics, Kulliyyah of Medicine, International Islamic University Malaysia Kuantan.
}

\begin{abstract}
Breast milk contains all basic nutrition needed by a child. Exclusive breastfeeding is recommended to all infants in their first 6 months of life. Infants who had been exclusively breastfed have a better health status compared to infants who were introduced with mixed feeding in their early life. Exclusive breastfeeding not only gives benefits to the child, but also to the mother. In infants it offers protective mechanism in lowering risk of gastrointestinal infection and promotes bonding between the mother and the child. The first case was a 2 years and 7 months old girl who was admitted to Hospital Tengku Ampuan Afzan Kuantan due to acute gastroenteritis with some dehydration. She had been admitted a month earlier due to pneumonia. She was breast fed exclusively for 3 months after she was born. Formula feeding was started after she turned 4 months old.. The second case was a 1 year and 4 months old boy who was hospitalized due to acute bronchiolitis. He was not breast fed due to no milk production. Islam views childhood as a critical phase in molding an individual. Parents have been entrusted by Allah to observe and fulfill the rights of the children in providing a conducive environment for them to develop and grow. A good healthcare and proper nutrition are among the child's rights that need to be filled by the parents. Islam emphasizes the importance of breastfeeding up to 2 years old as a way in providing good nutrition. Islam also provides solution for mothers who are unable to breastfed their child by adopting wet mother. Parents are responsible in providing good health and nutrition for their children. Breastfeeding is also highly encouraged by Islam because it provides medical benefits for both mother and children.
\end{abstract}

KEYWORDS: breastfeeding, Islam, infection, infant, children

\section{INTRODUCTION}

Human breast milk is biologically compatible for neonates and infants feeding. Its nutritional composition and non-nutritive bioactive factors optimize the growth and development of the infants. ${ }^{1}$ According to a systematic review on long term effects of breastfeeding done by WHO in 2007, breastfeeding has well-known health benefits; be it short- or long-term. ${ }^{2}$ It has also known to provide protection and reduction in mortality due to infectious disease in the first 2 years of life. ${ }^{3}$ Practicing optimal breastfeeding can reduce the number of hospitalization in children due to gastrointestinal, lower respiratory tract infection and allergic disease substantially. ${ }^{4,5}$ Despite that, it has aslo known benefit for child neurodevelopmental process as well as promoting the psychological bonding between the mother and the child. Given the provided health benefits, exclusive breastfeeding up to first 6 months of life has been made a normative standard for human infants with continuation of partial breastfeeding up to two years of age. ${ }^{6,7}$ This suggestion is consistent with the

Corresponding author:

Taufiq Hidayat

Department of Paediatrics,

Kulliyyah of Medicine,

International Islamic University Malaysia

Jalan Sultan Ahmad Shah, 25200 Kuantan

Email:dr_taufiq@iium.edu.my
Islamic teaching that promotes the continuation of the breastfeeding for children up to two years of age. $^{8}$ These two case reports show the importance of breastfeeding from the Islamic perspectives.

\section{Case 1}

A 2 years and 7 months old girl presented with 2 days history of mild grade fever, watery diarrhea and vomiting with some degree of dehydration following a family trip to Kuala Lumpur. They have all consumed the same food but none of them developed the symptoms except for her. The fever and episodes of loose stool started on the same day. It was a mild grade fever which was sudden in onset that was resolved with medication on first day of illness. In regards to the loose stool, the stool was watery with fluffy pieces and her diaper needed to be changed up to 10 times per day as compared to only 4 times per day during normal day. She developed non-projectile vomiting up to 4 times on that day. Initially the vomitus was watery with food particles and subsequently she only vomited clear fluid. Due to the illness, she became less active and had reduction in oral intake; she can only tolerate plain water. When she was brought to the hospital, she was admitted with diagnosis of Acute Gastroenteritis with some dehydration. For this admission, she was treated with fluids and oral rehydration salt for her dehydration. Investigations were done and the results suggested viral cause for acute gastroenteritis, evidence by the findings of 
lymphocytosis and monocytosis in full blood count. She was discharged after 4 days when she was clinically improved and encouraged to have oral intake at home. Upon further investigation, it was discovered she was admitted a month earlier for 4 days due to pneumonia. She had an uneventful birth history and her vaccination status was updated. The child had an exclusive breastfeeding only up to 3 months old due to a working mother and was put on formula feeding since then. On the day of admission, the child was on on adult diet.

\section{Case 2}

A 1 year and 4 months old boy admitted with history of fever for five days and worsening oral intake on the day of admission. Two weeks prior to his admission, the boy had cough that was initially a dry cough but later became chesty and productive. The cough worsened at night and was associated with post-tussive vomiting containing greenish sputum. It was also associated with clear discharge runny nose. He also had diarrhea for three days where the father needed to change the diapers for about four to five times a day/an hour (?). On the day of admission, the father said his son's urine was darker than usual. The boy had also poor oral intake since the fever developed. The father also claimed that his child sleep more during the day and was less active than usual. Upon admission, several investigations were done, and results show low neutrophils and increased lymphocyte count which indicated possible viral infections. The results also show All parameters in renal profile were normal with C-reactive protein was high at $27.3 \mathrm{mg} / \mathrm{L}$. Chest $x$-ray shows bilateral perihilar haziness more on right upper and lower zone. He was given intravenous C-Penicillin and was encouraged to eat orally. Further questionings revealed that the child had history of hospital admission ayear ago due to inguinal hernia and had to undergone an uneventful operation. Antenatally, her mother had gestational diabetes mellitus and was on subcutaneous insulin. The child was born via elective Caesarean section due to a history of two previous Caesarean sections. The child's immunization status was updated. Regarding the nutritional history of the child, the child had never been breastfed by the mother due to lack of milk production. He was given goat's milk as an alternative as he was allergic to cow's milk. At the time of the admission he was on adult diet.

\section{DISCUSSIONS}

Islam is a comprehensive religion that revealed by Allah for all mankind regardless of their skin colors, languages, or generations. It is made flexible that suits every aspects of human needs. The rights and responsibilities granted by Allah to mankind, including the rights of children, are mentioned in Quran and Hadith. ${ }^{9}$ Child is viewed with expectation and inspiration by Islam and it is a blessing from Allah that is always longed and sought for by His sincere believers. ${ }^{10}$ It is also mentioned in the Holy Quran saying that the offspring is a bounty from Allah to His believers: "To Allah belongs the kingdom of the Heavens and the Earth. He creates what He wills. He bestows female (offspring) upon whom He wills, and bestows male (offspring) upon whom $\mathrm{He}$ wills. Or $\mathrm{He}$ bestows both males and females, and makes whom He wills barren. Verily, $\mathrm{He}$ is The All-Knower and is able to do all things". ${ }^{11}$

Islamic teachings constructed a list of rights for children as a guideline in providing a conducive environment for children to develop and grow. Among the listed rights, the children's right to healthcare and proper nutrition were highlighted. As such, the modern medicine and Islamic teaching emphasize the children's health care to start as early as inside the womb. Both parents should pay their full attention in fulfilling their responsibility by taking good care of their children. The father should provide support for the conceiving mother both physically and spiritually throughout the pregnancy period until delivery. The mother must avoid involving or consuming anything that may cause harm to herself and the fetus. Once the mother had given birth to the baby, the mother should fulfill the rights of the child to be breastfed as it can satisfy the child physically, emotionally and spiritually. ${ }^{10}$

Breastfeeding is beyond than merely for nutritional purpose. It is a unique process, allowing interaction between the mother and the child both physically and psychologically. ${ }^{12}$ The importance of breastfeeding not only being stated in al-Quran but also had been scientifically proven. We would like to re-emphasize the importance of breastfeeding from the perspectives of modern evidence-based research. There were several studies done to determine the significance of breastfeeding in lowering the risk of infection in young infants. According to Duijts,et all [2010], exclusive breastfeeding for the first 4 months of life significantly reduce gastrointestinal and respiratory illnesses. ${ }^{13}$ This is supported by other studies in the United States where children below 6 months of age who had exclusive breastfeeding obtained the beneficial effect in preventing infectious diseases. ${ }^{14}$ In both cases, the child were not exclusively breastfeed by the mother. As an alternative, both of them were given formula milk. This is the main risk factor that contributes to the illnesses in both children.

Islamic teaching insists that the mother nurse and breastfed her newborn and it would be sinful upon her if she failed to do so without valid reason. As stated by the Prophet PBUH, "It is a grave sin for one to neglect a person whom he is responsible for sustaining". ${ }^{10}$ The Almighty Allah also had made the commandment in the Holy Quran, in Surah al-Baqara verse 233 saying that a competent mother should breastfed her child up to two years of age: "The mothers shall give suck to their children for two whole years, (that is) for those (parents) who desire to complete the term of suckling, but the father of the child shall bear the cost of the mother's food and clothing on a reasonable basis. No person shall 
have a burden laid on him greater than he can bear". ${ }^{8}$ Throughout the breastfeeding period, the mother should be supported in her nursing of her child. The father should pay her cost of living as she will be fully occupied by nursing his child. Despite fulfilling the child's need, the mother also simultaneously gaining reward from the Almighty Allah for her willingness to abide to His commandment to breastfeed her child.

Islam highly emphasizes the importance of breastfeeding and even provides alternatives for mothers who are unable to breastfeed their baby. This is mentioned in the Holy Quran, in the later part of verse 233 in Surah al-Baqara: "And if you decide on a wet mother for your offspring, there is no blame on you, provided you pay (the wet mother) what you offered, on equitable terms and fear Allah and know that Allah is All-Seer of what you do". ${ }^{8}$ By adopting wet mother, a child who cannot be breastfed by his or her own mother can ensure his good nutrition. In fact, Prophet Muhammad PBUH also had been breastfed by his own mother and later he was given to two different wet mothers.

The status of nursing mothers during the Holy month of Ramadhan was also highlighted by Islamic teachings. Consensus made among Muslim scholars had made exemptions for those nursing mother to not to fast during Ramadhan given their scenarios. As stated by Al-Mirdaawi in al-Insaaf, he mentioned the statement of Ibn 'Aqeel saying that nursing mother is required to fast if no effect on her and the baby. On the other hand, a nursing mother is allowed to break her fast if it affects herself and her baby. She however needs to replace the days that she had to breakfast. ${ }^{15}$ Shaykh Ibn 'Uthaymeen also mentioned in the Fataawa al-Siyam regarding the ruling of fasting for nursing mothers. He mentioned that those mothers who are able to perform fasting should proceed her fast and those who are affected by fast are exempted from fasting as she is considered as sick. ${ }^{15}$ This is consistent with Allah's saying in the Holy Quran, "and whoever is ill or on a journey, the same number [of days which one did not observe Sawm (fasts) must be made up] from other days". ${ }^{16}$

\section{CONCLUSIONS}

In conclusion, parents are responsible for providing good health and nutrition to their children as part of the children's rights. Practicing exclusive breastfeeding up to 6 months of age and continuation up to two years of age is part of providing good nutrition to the children. Islam highly values the practice of breastfeeding not only due to proven medical benefits but also as a way of seeking His pleasure with abiding to His commandment.

\section{REFERENCES}

1. Ballard O, Morrow AL Human Milk Composition: Nutrients and Bioactive Factors. Pediatric Clinics of North America 2013; 60:49-74.
2. World Health Organization. Long-term effect of breastfeeding: A Systematic Review [online].

Available at: http://www.who.int/ maternal_child_adolescent/documents/ breastfeeding_long_term_effects/en/. Accessed September 15, 2016.

3. WHO Collaborative Study Team on the Role of Breastfeeding on the Prevention of Infant Mortality. Effect of breastfeeding on infant and child mortality due to infectious diseases in less developed countries: a pooled analysis. Lancet 2000; 355:451-5.

4. Quigley MA, Kelly YJ, Sacker A Breastfeeding and hospitalization for diarrheal and respiratory infection in the United Kingdom Millennium Cohort Study. Pediatrics 2007; 119:e837-42.

5. Kramer MS, Kakuma R The optimal duration of exclusive breastfeeding: A systematic review. Adv Exp Med Biol 2004; 554:63-77.

6. Section on Breastfeeding. Breastfeeding and the use of human milk. Pediatrics 2012; 129:e82741.

7. World Health Organization. Global strategy for infant and young child feeding. The optimal duration of exclusive breastfeeding [online]. Available at http://apps.who.int/iris/ handle/10665/78801. Accessed September 15, 2016.

8. The Holy Quran. Surah Al-Baqara verse 233.

9. Stacey A What Islam says about children (part 1 of 5): God guarantees the rights of children [online]. Available at

http://www.islamreligion.com/articles/3584/vi ewall/what-islam-says-about-

children/\#.V93uMx5r29k. whatsapp. Accessed September 15, 2016.

10. United Nations Children's Fund, Al-Azhar University. Children in Islam: their care, upbringing and protection. New York: Pixeltone: 2005.

11. The Holy Quran. Surah as-Shura verses 49-50.

12. Kasule $\mathrm{OH}$. Breastfeeding. Islamic Medical Education Resources [online]. Available at http://www.omarkasuletib.blogspot.my/2011/04/070425l-breastfeeding.html. Accessed September 10, 2016.

13. Duijts L, Jaddoe VW, Hofman A, Moll HA. Prolonged and exclusive breastfeeding reduces the risk of infectious diseases in infancy. Pediatrics 2010; 126:e18-25.

14. Chantry CJ, Howard CR, Auinger P. Full breastfeeding duration and associated decrease in respiratory tract infection in US children. Pediatrics 2006; 117:425-32.

15. No author given. Ruling on fasting for pregnant women and breastfeeding mothers [online]. Available at http://islam.worldofislam.info/index.php/5pillars/76-ramadan-fasting/771-ruling-onfasting-for-pregnant-women-and-breastfeedingmothers. Accessed September 20, 2016.

16. The Holy Quran. Surah al-Baqara verse 185. 
